\title{
Public debt and financial stability: The case of economic community and monetary union of central Africa (EMCCA)
}

\author{
Assoumou Ondo \\ Faculty of Law and Economics, Omar Bongo University, Libreville, Gabon. \\ Received 31 July, 2017; Accepted 19 October, 2017
}

\begin{abstract}
This article analyzes the relationships between public debt and financial stability. Unlike traditional approaches based on linear panels (dynamic or static), we estimate a nonlinear regime change panel (PSTR) characterizing the relationships between public debt and financial stability for the member countries of the Economic Community, and Monetary Union of Central Africa (EMCCA). The results show that the public debt has contrasted effects on financial stability in EMCCA, according to regimes determined by the evolution of the price of oil.
\end{abstract}

Key words: Public debt, financial stability, oil price threshold.

\section{INTRODUCTION}

The recent financial crisis and the subsequent increase in public deficits put the study of bilateral interactions between public debt and financial stability back on the agenda. Indeed, public debt seems to have a destabilizing effect on the financial system; calling into question the hypothesis of a positive relationship between the two variables (Janda and Kravtsov, 2017). Therefore, the analysis of the relationships between public debt and financial stability has been the subject of an important literature.

On the theoretical level, the literature reveals two approaches. The first approach, developed in the work of Reinhart and Rogoff (2008, 2009 and 2011), Furceri and Zdzienicka (2012a; 2012b), Athanasios (2014) deals with the direct effects of financial stability on public debt. These effects are transmitted through two main channels:

(1) Provision of government support to the financial sector which increases domestic public debt, and

(2) Deleveraging of the financial sector, which by contracting economic activity, lower budgetary revenues and higher budgetary spending.

The second approach, discussed in particular by llgün (2016) and Janda and Kravtsov (2017), studies the influence of debt on financial stability. This part of the literature reveals two points of view. The first, defended in particular by Kumhof and Tanner (2005) and Ilgün

E-mail: assoumou7ondo@gmail.com.

Classification JEL: F34, G15, E40.

Authors agree that this article remain permanently open access under the terms of the Creative Commons Attribution License 4.0 International License 
(2010), argues that the public debt strengthens the stability of the financial sector through the security, high liquidity and steady flow of profits offered by the bonds State. The second point of view, supported by Houben et al. (2014), Ilgün (2016) and Janda and Kravtsov (2017), shows that a high public debt currency, would be a source of financial instability. The channels through which public debt influences financial stability are:

(1) The change in the level of risk of other assets denominated in the same currency as sovereign exposures; and

(2) The revaluation losses of government bonds (Janáček et al., 2012).

On the empirical level, various studies have examined the relationship between public debt and financial stability for different developed and developing countries. In the context of developed countries, Kutivadze (2011) estimates a panel model and provides empirical evidence that public debt is positively dependent on financial development.

In addition, Altaylıgil and Akkay (2013) study the case of the Turkish economy, and found a negative relationship between financial development and domestic indebtedness. Bordo and Meissner (2006) analyzed the effect of foreign debt on financial markets and they discovered that debt denominated in foreign currencies seems dangerous when mismanaged, but that a debt in the single currency alone does not always leads to a financial crisis.

More recently, Janda and Kravtsov (2017) analyze the effects of the national public debt on financial development, bank performance and private credit in the countries of Central Europe, Eastern Europe, Balkans and the Baltic. They show that in the short term, the growth of public debt has a negative effect on private credit in the Balkans and the Baltic countries.

In both emerging and developing countries, Hauner $(2008,2009)$ focuses on the impact of public debt on the performance of the banking sector. It shows that domestic public debt increases the profitability of the banking sector but reduces its effectiveness in the short term. For Ismihan and Ozkan (2012), public debt is likely to hamper financial development in countries where government credit accounts for a large share of total bank lending. More recently, Ilgün (2016) examines the relationship between public debt and financial development in 18 emerging countries over the period of 1987-2013. By estimating a non-stationary panel, he finds that government borrowing from national banks has a negative effect on long-term private credit. In the Economic and Monetary Community Of Central Africa (EMCCA) in particular, the effects of the increase in public debt are acute for at least two (2) reasons:

(1) The governments of the EMCCA member countries are facing a public finance crisis marked by the drastic reduction of this budgetary revenue in relation to the revenues derived from the exploitation of the oil. Hence, the increase in public spending of the State leads to a deterioration of budget deficits and an increase in public debt. In 2016, public debt, as a percentage of gross domestic product (GDP), is $46.6 \%$ in Gabon; $38 \%$ in Cameroon; $78.8 \%$ in the Republic of Congo; 24.6 per cent in Equatorial Guinea; $43.1 \%$ in Chad and $58.5 \%$ in the Central African Republic (IMF and World Bank reports, 2016);

(2) The financial development of the EMCCA member countries is still relatively weak despite some slight improvements. Indeed, "Although CEMAC's banking institutions are solid and stable, they remain fragile" (IMF, 2016). The banking sector of the EMCCA is marked by deterioration in the quality of the loan portfolio, characterized by an increase in the level of outstanding debts of CFAF 382 billion (+41.63\%).

The present reflection is a contribution to the study of the relationships between public debt and financial stability in EMCCA countries, in that it estimates a nonlinear panel of change of smooth transition regimes. Unlike previous studies, such a method makes it possible to propose an economic basis for changing regimes, to estimate the oil price threshold beyond which the financial system of the EMCCA zone would be destabilized and to determine the heterogeneous effects of the public debt on financial stability.

\section{Presentation of the model for determining the non- linear effects of public debt on financial stability}

The model of Ilgün (2016), which expresses a relationship between financial development, national public debt and a set of control variables, was improved.

$$
\mathrm{Fd}_{\mathrm{i}, \mathrm{t}}=\alpha_{0 \mathrm{i}}+\alpha_{1 \mathrm{i}} \mathrm{debt}_{\mathrm{i}, \mathrm{t}}+\alpha_{2 \mathrm{i}} \operatorname{control}_{\mathrm{i}, \mathrm{t}}+\epsilon_{\mathrm{i}, \mathrm{t}} \text { for } \mathrm{i}=1,2, \ldots, \mathrm{N} ; \mathrm{t}=1,2, \ldots, \mathrm{T}
$$

\section{Such as:}

$\mathrm{Fd}_{\mathrm{i}, \mathrm{t}}$, Financial development indicator;

Debt $_{i, t}$, public debt on GDP;

Control $_{\mathrm{I}, \mathrm{T}}$, The other determinants of financial development in country $\mathrm{i}$ and year $\mathrm{t}$; $\epsilon_{\mathrm{i}, \mathrm{t}}$, The error term.

In this study case, financial stability (Fs) is the endogenous variable of the model. It is measured by the 
ratio of doubtful loans to total assets; an indicator of financial stability used in the calculation of the financial vulnerability index (Albulescu, 2008). Given the conjuncture of five EMCCA countries, namely Cameroon, Congo, Gabon, Equatorial Guinea and Chad, linked to the results of oil sales, we consider that the marginal effects of public debt and control variables (control) on stability depend on the evolution of the price of oil (proil). Therefore, estimating a nonlinear panel integrating the price of oil as a threshold variable seems appropriate to determine the influence of the national public debt on the financial stability of the countries of the EMCCA zone. The change of plan panel is as follows:

$$
\begin{aligned}
& \mathrm{Fs}_{\mathrm{i}, \mathrm{t}}=\theta_{0 \mathrm{i}}+\left(\mathrm{b}_{1} \operatorname{debt}_{\mathrm{i}, \mathrm{t}}+\mathrm{b}_{2 \mathrm{i}} \operatorname{control}_{\mathrm{i}, \mathrm{t}}\right) * \mathrm{I}\left(\text { proil }_{\mathrm{i}, \mathrm{t}} \leq \gamma\right)+\left(\mathrm{c}_{1} \text { debt }_{\mathrm{i}, \mathrm{t}}+\mathrm{c}_{2 \mathrm{i}} \operatorname{control}_{\mathrm{i}, \mathrm{t}}\right) * \mathrm{I}\left(\text { proil }_{\mathrm{i}, \mathrm{t}}>\gamma\right)+\epsilon_{\mathrm{i}, \mathrm{t}} \text { for } \mathrm{i}= \\
& 1,2, \ldots, \mathrm{N} \text { et } \mathrm{t}=1,2, \ldots, \mathrm{T}
\end{aligned}
$$

\section{Such as:}

$\mathrm{Fs}_{\mathrm{i}, \mathrm{t}}$, Financial stability;

debt $_{i, t}$, public debt on GDP ;

petrole $_{i, t}$, the price of oil, but also the threshold variable;

proil $_{\mathrm{i}, \mathrm{t}}$, the price of oil ;

control $_{i, t}$, The other determinants of financial development in country $\mathrm{i}$ and year $\mathrm{t}$;

$\gamma$, is the price of oil threshold;

$b$ et $c$ are marginal effects in Regime 1 and 2, respectively;

$\mathrm{I}$, an indicator function which takes the value 1 if the condition in parenthesis is respected and 0 otherwise.

This equation can be rewritten as follows:

$\left\{\mathrm{Fs}_{\mathrm{i}, \mathrm{t}}=\theta_{0 \mathrm{i}}+\mathrm{b}_{1}\right.$ debt $_{\mathrm{i}, \mathrm{t}}+\mathrm{b}_{2 \mathrm{i}} \operatorname{control}_{\mathrm{i}, \mathrm{t}}+\epsilon_{\mathrm{i}, \mathrm{t}}$, if $\operatorname{proil}_{\mathrm{i}, \mathrm{t}} \leq \gamma$

$\left\{\mathrm{Fs}_{\mathrm{i}, \mathrm{t}}=\theta_{0 \mathrm{i}}+\mathrm{c}_{1}\right.$ debt $_{\mathrm{i}, \mathrm{t}}+\mathrm{c}_{2 \mathrm{i}}$ control $_{\mathrm{i}, \mathrm{t}}+\epsilon_{\mathrm{i}, \mathrm{t}}$, if proil $_{\mathrm{i}, \mathrm{t}}>\gamma$

In this study case, the control variables used are as follows:

(i) Private investment, determined by gross fixed capital formation,

(ii) Inflation rate,

(iii) Commercial coverage rate,

(iv) The net flow of foreign direct investment,

(v) The real interest rate and

(vi) Bank credit to the private sector (as a percentage of GDP).

\section{Empirical analysis}

We present first the methodology used and then proceed to interpret the results.

\section{METHODOLOGY}

The data used to estimate the effects of public debt on financial stability comes from the World Bank database and that of the International Monetary Fund (IMF) for the period of 1993-2015. These include the net flow of foreign direct investment (nfdi), credit to the private sector (creps), exports (exp), and imports (imp) of goods and services and public debt (debt), all expressed in Percentage of gross domestic product. The real interest rate (rir), the inflation rate (inr) and the gross domestic product (gdp) are included. In order to harmonize the series quantities and reduce the number of exogenous variables, GDP was linearized by the natural logarithm operator (ln) and the commercial coverage rate (ccr) was determined by carrying out the ratio of exports on imports as a percentage of GDP.

In order to analyze the non-linear effects of public debt on financial stability, we use recent developments of threshold models in panel data. The estimation of this model is carried out by the Hansen method (1999), taken over by Gonzàlez et al. (2005). The procedure for estimating a Panel smoothing Transition Regression (PSTR) takes place in three main stages:

The first step is to verify that the series lend themselves to a nonlinear estimation in panel data. These include Fisher's heterogeneity tests, Kennedy (1985), Hausman (1978), linear (Wald test, Fisher test and LR test) and multicollinearity tests. The second step deals with the desirability of a non-linearity with regime change. For this, a test was performed on the number of regimen. The test consists precisely in determining the value of the threshold which maximizes the sum of the squares of the residues such that:

$\hat{\gamma}=\operatorname{argmax}_{\gamma} \operatorname{SCR}(\gamma)$

The test procedure aims to test the null hypothesis of a threshold (or two regimes) against the alternative hypothesis of at least two thresholds (or at least three regimes). This test is performed by the MatLab software. Finally, the third step proceeds to the estimation of the PSTR model, using Gonzàlez et al. (2005) method. This estimate will be made using the Stata software 14 .

\section{RESULTS}

As for the preliminary tests, the results of the Fischer heterogeneity test show that the EMCCA countries are heterogeneous, confirming the possibility of estimating the model in the form of a panel (prob> $F=0.000$ ). The Kennedy multicollinearity test (1985) shows that the exogenous variables, taken in pairs, are not strongly correlated with one another.

The strongest correlation between exogenous appears between GDP and the commercial coverage rate (0.5968). Moreover, the Hausman test supports the idea that the most relevant model for estimating the relationship between public debt and financial stability has a fixed effect (prob> khi2 $=0.000$ ). As a result, it is possible to deduce a specific constant for each EMCCA country (Table 1). Table 1 presents the results of three linearity tests (Wald test, Fisher test and LR test). 
Table 1. linearity tests.

\begin{tabular}{lcc}
\hline Tests & Statistics & p-value \\
\hline Wald test $\left(\mathrm{LM}_{\mathrm{W}}\right)$ & 44.372 & $0.000^{*}$ \\
Fisher test $(\mathrm{LM})$ & 8.608 & $0.000^{*}$ \\
LR test $(\mathrm{LRT})$ & 54.080 & $0.000^{*}$ \\
\hline
\end{tabular}

Note: Linearity tests are shown here. The tests are based on a null hypothesis of linearity and an alternative hypothesis of nonlinearity. When the coefficient is preceded by $\left({ }^{*}\right)$ then the null hypothesis is rejected at the $1 \%$ threshold; for $\left({ }^{* *}\right)$ the null hypothesis is rejected at the $5 \%$ threshold; for $\left({ }^{* * *}\right)$ it is rejected at the $10 \%$ threshold.

Source: Author's calculations.

Table 2. Number of threshold tests.

\begin{tabular}{lccc}
\hline Tests & Statistics & p-value & $\begin{array}{c}\text { Number of } \\
\text { transition } \\
\text { function }\end{array}$ \\
\hline Wald test $(\mathrm{LM})$ & 15.945 & $0.026^{* *}$ & 1 \\
Fisher test $(\mathrm{LM})$ & 2.061 & $0.054^{\star * *}$ & 1 \\
LR test $(\mathrm{LRT})$ & 16.994 & $0.017^{\star *}$ & 1 \\
\hline
\end{tabular}

Note: Diagnosis tests are shown here. The tests are based on a null hypothesis of a single threshold (two regimes) and an alternative hypothesis of at least two thresholds (at least three regimes). When the coefficient is preceded by $\left({ }^{*}\right)$ the null hypothesis is rejected at the $1 \%$ threshold; for $\left({ }^{* *}\right)$ the null hypothesis is rejected at the $5 \%$ threshold; for $\left(^{* * *}\right)$ it is rejected at the $10 \%$ threshold.

Source: Author's calculations.

Table 3. Determinants of financial stability $\left(\mathrm{Fs}_{\mathrm{i}, \mathrm{t}}\right)$ (Endogenous variable: Financial stability $\left(\mathrm{Fs}_{\mathrm{i}, \mathrm{t}}\right)$ ).

\begin{tabular}{|c|c|c|}
\hline \multirow{2}{*}{ Exogenous variables } & \multicolumn{2}{|c|}{ Coefficients } \\
\hline & Regime $1 \gamma<94.1$ & Regime $2 \gamma>94.1$ \\
\hline Public debt $\left(\mathrm{debt}_{\mathrm{i}, \mathrm{t}}\right)$ & 0.00013 & $-0.4291^{*}$ \\
\hline Gross domestic product $\left(\operatorname{lgdp}_{\mathrm{i}, \mathrm{t}}\right)$ & $2.182^{\star \star *}$ & $2.8348^{* *}$ \\
\hline Credit to the private sector $\left(\operatorname{creps}_{\mathrm{i}, \mathrm{t}}\right)$ & $0.9111^{*}$ & $1.7163^{*}$ \\
\hline Inflation rate $\left(\mathrm{inr}_{\mathrm{i}, \mathrm{t}}\right)$ & 0.0312 & 0.0367 \\
\hline Commercial coverage rate $\left(\mathrm{ccr}_{\mathrm{i}, \mathrm{t}}\right)$ & 1.0448 & -1.2487 \\
\hline Real interest rate $\left(\operatorname{rir}_{\mathrm{i}, \mathrm{t}}\right)$ & -0.0286 & -0.1540 \\
\hline Net flow of foreign direct investment $\left(\mathrm{nfdi}_{\mathrm{i}, \mathrm{t}}\right)$ & 0.00268 & -0.3417 \\
\hline Constant & -22.894 & -22.894 \\
\hline
\end{tabular}

Note: This table presents the determinants of Financial Stability. The Student tests on each coefficient are based on a null hypothesis of zero significance and an alternative hypothesis of non-significance at zero. When the coefficient is preceded by $\left({ }^{*}\right)$ then the null hypothesis is rejected at the $1 \%$ threshold; for $\left(^{* \star}\right)$ the null hypothesis is rejected at the $5 \%$ threshold; for $\left({ }^{* * *}\right)$ it is rejected at the $10 \%$ threshold.

Source: Author's calculations.

The results in Table 1 lead to the rejection of the linearity hypothesis at the critical threshold of $1 \%$. This reflects the existence of a non-linear relationship between financial stability and its explanatory variables. It is now necessary to determine the threshold number of the model. Table 2 presents the results of three tests on the threshold number (Wald test, Fisher test and LR test).
The results of Table 2 allow to reject the alternative hypothesis of at least two thresholds with the probabilities obtained from the various statistical tests of Wald, Fisher and LRT above the critical threshold of $1 \%$. There is therefore a single threshold for the price of oil above which public debt impacts financial stability differently. Table 3 presents the results from the estimation of the 
heterogeneous effects of public debt on financial stability. The overall significance of the estimated model (prob> $F=0.0000$ ) at $1 \%$ and of the oil threshold price $\mathrm{Y}=$ 94.1 confirm the relevance of the nonlinear relation to two regimes.

The results in Table 3 reveal the existence of a nonlinear effect of public debt on the financial stability of the EMCCA member countries, showing that the influence of the public debt depends on the evolution of the price of oil. Indeed, when the price of oil is below 94.1 USD (regime 1), the public debt could have a positive effect $(0.00013)$ on the outstanding debts of the banking sector. This confirms the results of Ismihan and Ozkan (2012), Ilgün (2016) and Janda and Kravtsov (2017) that public debt deteriorates financial stability.

More precisely, the study corroborates the findings of Ismihan and Ozkan (2012) because, for EMCCA banks, the holding of government bonds remains considerably less damaging than the supply of credit to the private sector (0.9111). As a result, subregional banks, which are prone to default risk, prefer to increase their lending to the government rather than lending to households and private enterprises. The results also show that, in excess of 94.1 USD (regime 2), public debt reduces the bad debts $(-0.4291)$ of banks in the EMCCA zone. This is in line with the results of Kumhof and Tanner (2005) and Ilgün (2010) that public debt contributes to the maintenance of financial stability. Indeed, in this regime 2 , the EMCCA significantly states the increase in their oil revenues, which has the effect of strengthening the confidence of the banks with regard to government bonds. This is considered as a very liquid assets and with certain returns, as opposed to credit to the private sector, which remains very risky (1.716) for banks and the entire financial system.

Moreover, the increase in economic activity $\left(\operatorname{lgdp}_{\mathrm{i}, \mathrm{t}}\right)$ seems to reinforce the banks' risk-taking; resulting in increased credit to the private sector. As a result, doubtful loans increase in both regimes and increase the risk of financial instability in the EMCCA countries. The inflation rate, the net flow of foreign direct investment, the commercial coverage rate and the interest rate have no significant effect on the financial stability of the EMCCA countries, since they are International financial system.

\section{Conclusion}

In this paper, we have studied the relationship between public debt and financial stability in the EMCCA member countries from a nonlinear panel. After estimating the model by the method of Gonzàlez et al. (2005), the study highlights two regimes in the relationship between the two variables and determines the oil price threshold above which public debt would enhance financial stability in the subregion. Indeed, the results show that, initially, public debt could deteriorate the financial system via bad debts; then, strengthen it when the oil is sold at more than USD 94.1. However, such an effect may also depend on the structure of the public debt (short term and liabilities denominated in foreign currency). It may therefore be interesting to take this dimension into account in a dynamic analysis of the effects of public debt on financial stability.

\section{CONFLICT OF INTERESTS}

The author has not declared any conflict of interests.

\section{ACKNOWLEDGEMENTS}

The author sincere thanks go to the various members of the International Center for Reflexion in Economics and Management for Development (CIREGED) for the day-today discussions.

\section{REFERENCES}

Albulescu CT (2008). Assessing Romanian financial sector stability: the importance of the international economic climate. MPRA Paper, pp. 16581.

Altayligil YB, Akkay RC (2013). The effect of the domestic debt on the financial development: a case study for Turkey. Int. J. Econ. Finance. 5:64. doi: 10.5539/ijef.v5n5p64

Athanasios OT (2014). Financial stability indicators and public debt developments, Q. Rev. Econ. Financ. 54 (2):158-179.

Bordo MD, Meissner CM (2006). The role of foreign currency debt in financial crises: $1880-1913$ vs. 1972-1997. J. Bank. Financ. 60:32993329.

Furceri D, Zdzienicka A (2012). How costly are debt crises? J. Int. Money Financ. Elsevier 31(4):726-742.

Furceri D, Aleksandra Z (2012). The Consequences of Banking Crises for Public Debt. Int. Financ. 15(3):289-307.

Gonzàlez A, Teräsvirta T, Dijk DV (2005). Panel Smooth Transition Regression Models. Research P 165.

Hansen B (1999). Threshold effects in non-dynamic panels : Estimation, testing and inference. J. Econom. 93(2): 345-368.

Hauner D (2008) Credit to government and banking sector performance. J. Bank. Financ. 32:1499-1507.

Hauner D (2009) Public debt and financial development. J. Dev. Econ. 88:171-183.

Hausman JA (1978). Specification tests in econometrics . Econometrica 46(6):1251-1271.

Houben A, Jan K, Garry S (2004). Toward a Framework for Safeguarding Financial Stability, IMF Working Paper 04:101. (Washington: International Monetary Fund).

Ilgün MF (2016). Financial development and domestic public debt in emerging economies: A panel cointegration analysis. J. Appl. Econ. Bus. Res. 6:284-296.

International Monetary Fund (IMF) (2016). Fiscal Monitor, October 2016 : Debt: Use It Wisely.

Ismihan M, Ozkan F (2012). Public debt and financial development: A theoretical exploration. Econ. Lett. 115:348-351. doi: 10.1016/ j.econlet. 2011. 12.040.

Janáček K, Hlaváče KM, Komárek L, Komárková Z (2012). Impacts of the Sovereign Default Crisis on the Czech Financial Sector, CNB, Financial Stability Report 2011/2012.

Janda K, Oleg K (2017). Time-varying Effects of Public Debt on the Financial and Banking Development in the Central and Eastern Europe, MPRA posted 7 March 2017 15:28 UTC. P 77325. 
Kennedy P (1985). A Guide to Econometrics. Cambridge: The MIT Press.

Kumhof M, Tanner E (2005). Government Debt: A Key Role in Financial Intermediation, IMF. 05:57 (Washington: International Monetary Fund).

Kutivadze N (2011). Public debt and financial development. University of Milano. 2011-2013.

Reinhart C, Rogoff K (2008). Banking Crises: An Equal Opportunity Menace. NBER. P 14587.

Reinhart C, Rogoff K (2009). This Time is Different: Eight Centuries of Financial Folly, Princeton University Press.
Reinhart C, Rogoff K (2011). From financial crash to debt crisis. Am. Econ. Rev. 101:1676-1706. Eastern Europe, MPRA Paper №77325, Posted 7 March 2017 15:28 UTC. 